\title{
TAFSIR MAQĀŞID DENGAN PENDEKATAN GENDER TERHADAP AYAT-AYAT HUKUM KELUARGA
}

\author{
Suqiyah Musafa'ah \\ Dosen Fakultas Syariah dan Hukum UIN Sunan Ampel \\ Surabaya. Email: uqiefais@gmail.com
}

\begin{abstract}
This research focuses on rediscovering the verses about the establishment of the family law and the events or the reason of the revelation of the verses. It is then analyzed within the frame of maqassid and gender approach. The verses can be classified into 3 areas, among others; (a) family law verses starting from marriage to separation either due to death or divorce, (b) the guardianship law verses of the immature child; (c) verses of family wealth law (amwal al-usrah) which includes inheritance, wasiyat, endowment and everything related to acceptance and or giving. The usage of maqassid and gender perspectives are based on chapter al-Rüm (30): 21; that marriage rules are aimed to building a harmonious family, which spawns a loving relationship between husband and wife, and compassion among their children. The harmony is awakened through close relationship among husband, wife, and children who are able to fulfill their rights and obligations of each with full of love and affection. Each has the ability to control such rights and obligations freely and proportionately.
\end{abstract}

Keywords: Maqāşidi commentary, social commentary of family law verses, gender within an-Qur'an

Abstrak: Penelitian ini mencoba menemukan kembali ayat-ayat yang membangun Hukum Keluarga dan peristiwa yang menjadi latar belakang turunnya, lalu memahaminya dalam bingkai maqāşid dengan pendekatan gender. Ayat-ayat tersebut dapat diklasifikasi dalam 3 bidang antara lain; (a) ayat-ayat hukum keluarga (usrab) yang dimulai dari peminangan sampai perpisahan, baik karena ada yang wafat maupun karena terjadi perceraian, (b) ayat-ayat hukum perwalian terhadap anak yang belum dewasa; (c) ayatayat hukum kekayaan keluarga (amwäl al-usrah) yang mencakup waris, wasiyat, wakaf dan sejenisnya yang berkaitan dengan penerimaan dan atau pemberian. Penafsiran terhadap ayat-ayat tersebut menggunakan perspektif maqāșid dengan pendekatan gender berpijak dari QS.al-Rūm (30): 21; bahwa aturan perkawinan bertujuan membangun keluarga yang sakinah (harmonis), yang melahirkan hubungan saling cinta diantara suami, istri, dan kasih sayang diantara anak-anak mereka. Keharmonisan tersebut terbangun melalui hubungan antara suami, isteri, dan anak yang mampu memenuhi hak dan kewajiban masing-masing dengan penuh cinta dan kasih sayang. Masing-masing memiliki kemampuan mengontrol hak dan kewajiban tersebut secara bebas dan proporsional.

AL-HUKAMA

The Indonesian Journal of Islamic Family Law

Volume 07, Nomor 02, Desember 2017; ISSN:2089-7480 
Suqiyah Musafa'ah: Tafsir Maqasid dengan Pendekatan Gender...

Kata Kunci: Tafsir Maqāssid, Tafsir Sosial ayat-ayat Hukum Keluarga, Gender dalam Penafsiran Al-Qur'an

\section{Pendahuluan}

Al-Qur'an diturunkan dalam rangka menegakkan misi rahmat bagi alam semesta beserta penghuninya tanpa ada diskriminasi seksual, warna kulit, etnis, dan ikatan-ikatan primordial lainnya.2 Karena itu salah satu misinya adalah membebaskan manusia dari berbagai bentuk diskriminasi dan penindasan, 3 hubungan antar relasi merupakan komunikasi sosial untuk saling melengkapi.4 Namun, dalam historis-empiris justru cenderung menunjukkan sebaliknya. Status dan peran perempuan di berbagai masyarakat muslim pada umumnya masih mengalami ragam ketidakadilan, marginalisasi, subordinasi, stereotip, kekerasan dan beban kerja.5 Ironisnya, ketimpangan peran sosial perempuan tersebut berkembang dan dipertahankan dengan dalih agama. Agama dilibatkan untuk melestarikan kondisi di mana kaum perempuan tidak menganggap dirinya sejajar dengan laki-laki.

Dalam sejumlah kitab tafsir dan fikih, terdapat penjelasan dan tambahan penjelasan yang cenderung memarjinalkan kaum perempuan. Hal ini menujukkan, bahwa penafsiran keagamaan memiliki peran penting dalam melegitimasi dominasi atas kaum perempuan. Banyaknya penafsiran yang mengandung bias tersebut, selanjutnya dijadikan rujukan untuk memformulasikan kembali entitas Islam yang murni dan ideal. Padahal tafsiran-tafsiran yang berkembang itu bukan representasi ajaran Islam yang murni dan ideal, karena ajaran Islam yang murni dan ideal pada dasarnya tidak berpihak pada kondisi yang bertentangan dengan semangat persamaan yang diajarkan melalui risalahnya.

Sebagai bentuk kritik dan keprihatinan terhadap kecenderungan penafsiran sebagaimana disebutkan di atas, maka

1 Q.S. al-Anbiya (21): 107.

2 Q.S. Surah Saba' (34): 28.

3 Q.S. Surah al-Hujurāt (49): 13.

4 Q.S. Surah Zukhrūf (43): 32.

5 Penjelasan tentang jenis-jenis ketidakadilan yang banyak dialami perempuan, lihat Mansour Fakih, Analisis Gender dan Transformasi Sosial (Yogyakarta: Pustaka Pelajar, 1999), 12-23.

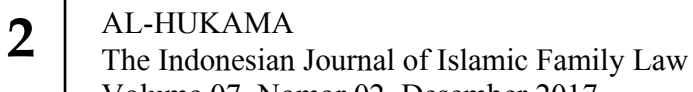
Volume 07, Nomor 02, Desember 2017
} 
lahir tafsir-tafsir kontekstual pada era modern sampai dengan posmodern yang bertujuan melakukan pembacaan ulang terhadap tafsir-tafsir keagamaan yang cenderung memarjinalkan kaum perempuan. Sebagaimana halnya tafsir keagamaan model lain yang telah menjadi bagian dari dinamika kehidupan umat, tafsir kontekstual yang lahir tersebut sejatinya juga perlu diapresiasi secara memadai, sepanjang terbukti memenuhi prinsip-prinsip dan kaedahkaedah penafsiran yang disepakati.

Isu gender yang memiliki porsi besar dalam hukum keluarga sangat mendominasi dalam penafsiran yang memarjinalkan kaum perempuan dalam kitab-kitab tafsir dan fikih, bahkan sampai dengan saat ini di wilayah Indonesia yang berasas Pancasila. Karena itu perlu membangun mindset gender mainstreaming dalam penafsiran kontekstual yang melibatkan maqūșid sharìah demi memformulasikan kembali entitas Islam yang murni dan ideal, dan Islam yang ramah pada alam semesta, sehingga mampu memberikan perlindungan bagi perempuan dan anak.

Berdasarkan latar belakang tersebut di atas, maka kajian tafsir maquassid dengan pendekatan gender terhadap ayat-ayat hukum keluarga dapat dirumuskan antara lain: ayat apa saja yang membangun hukum keluarga? bagaimana memahami ayat-ayat hukum keluarga dalam bingkai maquassid dengan pendekatan gender? studi tafsir maqäșid dengan pendekatan gender terhadap ayat-ayat hukum keluarga bertujuan antara lain: mengklasifikasikan ayat-ayat yang membangun hukum keluarga, melakukan pembacaan ulang terhadap ayat-ayat hukum keluarga dalam bingkai maqāșid dengan pendekatan gender.

Secara teoritis, kajian tafsir maqāşid dengan pendekatan gender terhadap ayat-ayat hukum keluarga, diharapkan mampu memformulasikan kembali aturan dan hukum keluarga menurut misi Islam yang murni, ideal, yang ramah perempuan dan para pihak yang termarginalkan, sehingga mampu memberikan perlindungan bagi perempuan dan anak di Indonesia. Secara praktis, penelitian ini diharapkan mampu memberikan solusi dalam membangun advokasi sosial bagi perlindungan Perempuan dan anak di Indonesia. 
Tafsir Maqāşid dengan pendekatan gender terhadap ayat-ayat hukum keluarga menggunakan pendekatan maqāşid shariah dan analisis gender dalam pertimbangan menemukan makna yang tepat terhadap ayat-ayat hukum keluarga yang sejalan dengan kebijakan dan keadilan bangsa Indonesia yang berasas Pancasila.

\section{Ayat-ayat yang Membangun Hukum Keluarga}

Ayat-ayat yang membangun hukum keluarga dapat dikelompokkan ke dalam 3 bidang antara lain;6

1. Ayat-ayat hukum Keluarga (usrab) yang dimulai dari peminangan sampai perpisahan, baik karena ada yang wafat maupun karena terjadi perceraian.

2. Ayat-ayat hukum Perwalian terhadap anak yang belum dewasa.

3. Ayat-ayat hukum kekayaan keluarga (amwäl al-usrah); yang mencakup waris, wasiyat, wakaf dan sejenisnya yang berkaitan dengan penerimaan dan atau pemberian.

Tabel 3. 1

Ayat-ayat yang Membangun Hukum Keluarga (usrah)

\begin{tabular}{|r|l|c|c|}
\hline No & \multicolumn{1}{|c|}{ Hukum Keluarga (usrah) } & \multicolumn{2}{c|}{ Sabab Nuzūl } \\
\hline 1 & $\begin{array}{l}\text { Ayat-ayat yang membangun tujuan, } \\
\text { hikmah, aturan, dan konsep perkawinan }\end{array}$ & ada & Tidak ada \\
\hline \multirow{5}{*}{} & QS. al-Rūm (30): 21; & & $\sqrt{ }$ \\
\hline & QS. al-Nūr (24): 3; & $\sqrt{ }$ & \\
\hline & QS. al-Nūr (24): 6-9, & $\sqrt{ }$ & \\
\hline & QS. al-Nūr (24): 32-33; & $\sqrt{ }$ & \\
\hline & QS. al-Baqarah (2):187, 221; 223 & $\sqrt{ }$ & \\
\hline & QS. al-Māidah (5): 5; & & $\sqrt{ }$ \\
\hline & QS. al-Mumtahanah (60):10; & & $\sqrt{ }$ \\
\hline \multirow{5}{*}{2} & $\begin{array}{l}\text { Ayat-Ayat yang membangun aturan } \\
\text { Khițbah }\end{array}$ & & \\
\hline & QS. al-Baqarah (2):235; & & $\sqrt{ }$ \\
\hline 3 & $\begin{array}{l}\text { Ayat-Ayat yang membangun konsep } \\
\text { mahar atau maskawin }\end{array}$ & \\
\hline
\end{tabular}

6 Wahbah al-Zuhayly, al-Fiqh al-Islām wa Adillatuh, (Beirut: Dār al-Fikr, 2004), 6487. 


\begin{tabular}{|c|c|c|c|}
\hline & QS. al-Nisā' (4): 4; & $\sqrt{ }$ & \\
\hline & QS. al-Nisā' (4): 19, & $\sqrt{ }$ & \\
\hline & QS. al-Nisā' (4): 20-21; & & $\sqrt{ }$ \\
\hline & QS. al-Nisā' (4): 24; & $\sqrt{ }$ & \\
\hline & QS. al-Nisā' (4): 25; & & $\sqrt{ }$ \\
\hline & QS. al-Baqarah (2): 229; & $\sqrt{ }$ & \\
\hline & QS. al-Baqarah (2): 236 & & $\sqrt{ }$ \\
\hline & QS. al-Baqarah (2): 237; & & $\sqrt{ }$ \\
\hline & QS. al-Baqarah (2): 241; & $\sqrt{ }$ & \\
\hline 4 & $\begin{array}{l}\text { Ayat-Ayat yang membangun aturan } \\
\text { radäa'ah dan wanita yang haram dinikahi }\end{array}$ & & \\
\hline & QS. al-Nisā' (4): 22-24; & $\sqrt{ }$ & \\
\hline & QS. al-Ahzāb (33): 50-51; & $\sqrt{ }$ & \\
\hline 5 & $\begin{array}{l}\text { Ayat-Ayat tentang Hak dan Kewajiban } \\
\text { Suami, Istri, Anak, Perwalian dan } \\
\text { Masalah Nafkah. }\end{array}$ & & \\
\hline & QS. al-Baqarah (2): 233; & & $\sqrt{ }$ \\
\hline & QS. al-T,alāq (65): 6-7; & & $\sqrt{ }$ \\
\hline & Q.S. al-Nūr (24): 33 & $\sqrt{ }$ & \\
\hline & QS. al-Nisā' (4): 32; & $\sqrt{ }$ & \\
\hline & $\begin{array}{l}\text { QS. al-Ahzāb (33): 35; QS. al-Nisā' (4): } \\
\text { 34; }\end{array}$ & $\sqrt{ }$ & \\
\hline 6 & Ayat-Ayat hukum Poligami. & & \\
\hline & QS. al-Nisā' (4): 3; & & $\sqrt{ }$ \\
\hline & QS. al-Ahzāb (33): 50-53; & & \\
\hline & QS. al-Nisā' (4): 129; & & $\sqrt{ }$ \\
\hline 7 & Ayat-Ayat Hukum Perceraian & & \\
\hline & $\begin{array}{l}\text { a. Ayat tentang Nushüz, Shiqäq dan } \\
\text { penyelesaiannya }\end{array}$ & & \\
\hline & QS. al-Nisā' (4): 34-35; & & $\sqrt{ }$ \\
\hline & QS. al-Nisā' (4): 128; & $\sqrt{ }$ & \\
\hline & $\begin{array}{l}\text { b. Ayat-ayat hukum Talak dan Rujuk } \\
\text { antara lain; berisi aturan tentang tata }\end{array}$ & & \\
\hline
\end{tabular}


Suqiyah Musafa'ah: Tafsir Maqasid dengan Pendekatan Gender...

\begin{tabular}{|c|c|c|}
\hline $\begin{array}{l}\text { cara mentalaq istri dan etika } \\
\text { memperlakukannya }\end{array}$ & & \\
\hline QS. al-Baqarah (2): 228-230; & $\sqrt{ }$ & \\
\hline QS. al-Baqarah (2): 231-232; & $\sqrt{ }$ & \\
\hline QS. al-Nisā' (4): 34; & $\sqrt{ }$ & \\
\hline Q.S. al-Baqarah (2): 237 & & $\sqrt{ }$ \\
\hline QS. al-Baqarah (2): 236; & & $\sqrt{ }$ \\
\hline QS. al-Baqarah (2): 240; & & $\sqrt{ }$ \\
\hline QS. al-Baqarah (2): 241; & & $\sqrt{ }$ \\
\hline QS. al-Ţalāq (65): 1,2,3; & $\sqrt{ }$ & \\
\hline $\begin{array}{l}\text { c. Ayat tentang hukum } I l \vec{a} \text { dan zihär dan } \\
\text { konsekuensinya }\end{array}$ & & \\
\hline QS. al-Baqarah (2): 226-227; & & $\vec{V}$ \\
\hline QS. al-Mujādalah (58): 1-4; & $\sqrt{ }$ & \\
\hline QS. al-Nūr (24): 6-9, & $\sqrt{ }$ & \\
\hline $\begin{array}{l}\text { d.Ayat tentang Iddah dan hukumnya serta } \\
\text { konsekuensinya }\end{array}$ & & \\
\hline QS. al-Baqarah (2): 228; & & $\sqrt{ }$ \\
\hline QS. al-Baqarah (2): 231; & & $\sqrt{ }$ \\
\hline QS. al-Baqarah (2): 234-235; & & $\sqrt{ }$ \\
\hline QS. al-T, Talāq (65): 4-7; & $\sqrt{ }$ & \\
\hline QS. al-Ahzāb (33): 49; & & $\sqrt{ }$ \\
\hline
\end{tabular}

Tabel 3. 2

Ayat-Ayat Yang Membangun

Hukum Perwalian Terhadap Anak Yang Belum Dewasa

\begin{tabular}{|l|l|c|c|}
\hline NO & \multicolumn{1}{|c|}{$\begin{array}{c}\text { Hukum Perwalian terhadap anak yang } \\
\text { belum dewasa }\end{array}$} & \multicolumn{2}{|c|}{ Sabab Nuzūl } \\
\hline \multirow{5}{*}{} & \begin{tabular}{c} 
Ayat-Ayat Hukum Hadānah dan Adopsi \\
\cline { 2 - 4 }
\end{tabular} & ada & Tidak ada \\
\cline { 2 - 4 } & QS. al-Baqarah (2): 220; & $\sqrt{ }$ & \\
\cline { 2 - 4 } & QS. al-Nisā' (4): 2; & $\sqrt{ }$ & \\
\cline { 2 - 4 } & QS. al-Nisā' (4): 5-6; & & $\sqrt{ }$ \\
\cline { 2 - 5 } & QS. al-Nisā' (4): 9-10; & & $\sqrt{\mid}$ \\
\hline
\end{tabular}

6 \begin{tabular}{l|l} 
AL-HUKAMA \\
The Indonesian Journal of Islamic Family Law \\
Volume 07, Nomor 02, Desember 2017
\end{tabular} 


\begin{tabular}{|l|l|c|c|}
\hline & QS. al-Nisā' (4): 127; & $\sqrt{ }$ & \\
\cline { 2 - 4 } & QS. al-Ahzāb (33): 4-5; & $\sqrt{ }$ & \\
\hline
\end{tabular}

Tabel 3.3

Ayat-Ayat Yang Membangun Kategori Hukum Kekayaan Keluarga (Amwäl Al-Usrah)

\begin{tabular}{|c|c|c|c|}
\hline $\mathrm{NO}$ & Hukum kekayaan keluarga (amwāl) & Sab & Juzūl \\
\hline \multirow[t]{19}{*}{1} & $\begin{array}{r}\text { Ayat-ayat Hukum wasiyat dapat dibagi ke } \\
\text { dalam beberapa periode; yaitu Periode } \\
\text { Makkah Pertama }\end{array}$ & ada & $\begin{array}{c}\text { Tidak } \\
\text { ada }\end{array}$ \\
\hline & QS. Al-'Aşr (103): 3 & & $\sqrt{ }$ \\
\hline & QS.al-Balad (90): 17; & & $\sqrt{ }$ \\
\hline & $\begin{array}{l}\text { Ayat-ayat Hukum wasiyat yang termasuk } \\
\text { dalam periode Makkah kedua }\end{array}$ & & $\sqrt{ }$ \\
\hline & QS al-Dhāriyāt (51): 53, & & $\sqrt{ }$ \\
\hline & QS Yāsīn (36): 50, dan & & $\sqrt{ }$ \\
\hline & QS Maryam (19): 31; & & $\sqrt{ }$ \\
\hline & $\begin{array}{l}\text { Ayat-ayat Hukum wasiyat yang termasuk } \\
\text { dalam periode Makkah ketiga }\end{array}$ & & $\sqrt{ }$ \\
\hline & QS. Al-An'ām (6): 144; 151-153; & & $\sqrt{ }$ \\
\hline & QS. Luqmān (31): 14; & & $\sqrt{ }$ \\
\hline & QS. Al-Shūrā (42): 13; & & $\sqrt{ }$ \\
\hline & QS.A-Ahqāf (46): 15; & & $\sqrt{ }$ \\
\hline & QS.al-'Ankabūt (29): 8; & & $\sqrt{ }$ \\
\hline & QS. al-Mā’idah (5):106; & & $\sqrt{ }$ \\
\hline & $\begin{array}{r}\text { Ayat-ayat Hukum wasiyat yang termasuk } \\
\text { dalam periode Madinah }\end{array}$ & & $\sqrt{ }$ \\
\hline & QS.al-Baqarah (2):132; 180; 182; & & $\sqrt{ }$ \\
\hline & QS.al-Baqarah (2): 240; & $\sqrt{ }$ & \\
\hline & QS. al-Nisā' (4): 131; & & $\sqrt{ }$ \\
\hline & QS. al-Mā'idah (5):106; & $\sqrt{ }$ & \\
\hline 2 & Ayat-Ayat Hukum Kewarisan & & \\
\hline
\end{tabular}


Suqiyah Musafa'ah: Tafsir Maqasid dengan Pendekatan Gender..

\begin{tabular}{|l|l|c|c|}
\hline \multirow{5}{*}{} & QS. al-Nisā' (4): 19; & & $\sqrt{ }$ \\
\hline & QS. al-Nisā' (4): 7; & $\sqrt{ }$ & \\
\hline & QS. al-Nisā' (4): 9; & $\sqrt{ }$ & \\
\hline & QS. al-Nisā' (4): 11-12 & $\sqrt{ }$ & \\
\hline & QS. al-Nisā' (4): 33; & & $\sqrt{ }$ \\
\hline & QS. al-Nisā' (4): 176 & & $\sqrt{ }$ \\
\hline \multirow{5}{*}{3} & Ayat-Ayat Hukum Wakaf & & \\
\hline & QS. Ali-Imrān (3): 92; & & $\sqrt{ }$ \\
\hline & QS. Al-Hajj (22): 77; & & $\sqrt{ }$ \\
\hline & QS. Al-Baqarah (2): 261; & & $\sqrt{ }$ \\
\hline & QS. Al-Baqarah (2): 267; & $\sqrt{ }$ & \\
\hline
\end{tabular}

\section{Penafsiran Ayat-Ayat Hukum Keluarga Pada Masa Rasulullah} saw

1. Ayat-ayat Hukum Perkawinan

Ayat-ayat yang membangun tujuan, hikmah, aturan, dan konsep perkawinan antara lain; QS. al-Rūm (30): 21; QS. al-Nūr (24): 3; QS. al-Nūr (24): 6-9, QS. al-Nūr (24): 32-33; QS. alBaqarah (2):187, 221; 223 QS.al-Māidah (5): 5; QS. alMumtahanah (60):10;

Ayat-ayat di atas, membangun aturan pernikahan, dan tujuannya. Pada masa Nabi Muhammnad saw, komunitas muslim telah melaksanakan aturan pernikahan di bawah bimbingan Rasulullah saw. berdasarkan tradisi mereka selama tidak ada teguran dari Allah melalui Rasulullah saw.

Aturan pernikahan tersebut dalam rangka menjaga tujuan pernikahan yang telah tertuang dalam ayat 21 QS. al-Rūm (30) yang termasuk ayat makkiyah, dan dikuatkan dengan penjelasan ayat 189 QS. al- A'rāf (7), bahwa pernikahan merupakan salah satu bukti kekuasaan Allah. Pernikahan tersebut merupakan media mempertemukan pasangan hidup demi mencapai ketentraman, keharmonisan dan kedamaian dalam menjalankan tugas kemanusiaannya.

Tujuan pernikahan yang suci dan sangat fundamental tersebut harus dibangun berdasarkan pola hidup yang suci pula, 
karena itu, maka ayat 3, 4, dan 5 QS. al-Nūr (24) harus diindahkan demi mencapai sakinah tersebut. Karena itu bila hubungan antara suami istri tidak lagi mencapai sakinah akibat terjadinya perselingkuhan, dan ketidak percayaan dari salah satu pasangan suami istri tersebut, maka ayat 6 sampai dengan 9 QS. al-Nūr (24) memberikan solusinya.

Karena masyarakat Arab termasuk masyarakat patriarki, maka demi melindungi kehormatan para perempuan, ayat 32 dan 33 QS. al-Nūr (24) memberikan aturan dan etika dalam melaksanakan pernikahan yang harmonis dan sakinah, baik secara psikologis maupun ekonomis. Ayat 187, 223 QS. al-Baqarah (2) memberikan hak yang sama bagi pasangan suami istri dalam membangun keluarga yang harmonis. Sedang larangan menikah dengan pasangan yang beda ideologi sebagaimana tertuang dalam ayat 221 QS. al-Baqarah (2), adalah juga dalam rangka menjaga tujuan pernikahan yang sakinah dan harmonis, karena itu dalam keadaan tertentu sebagaimana kasus yang direkam ayat 5 QS.alMāidah (5) dan ayat 10 QS. al-Mumtahanah (60) pada awal Islam, juga diberikan toleransi demi menjaga keharmonisan tersebut.

2. Ayat yang membangun aturan Khițbah antara lain; Q.S. alBaqarah (2):235; Ayat tersebut memberikan aturan dan etika melamar kepada perempuan yang masih dalam masa iddah.

3. Ayat-Ayat yang membangun konsep mahar atau maskawin dan mut'ah antara lain; QS. al-Nisā' (4): 4, 19, 20-21, 24; 25; QS. alBaqarah (2): 236, 237, 229,241; Ayat-ayat di atas secara tegas membangun hukum wajib bagi suami memberikan maskawin atau mahar dalam membangun ikatan perkawinan, dan wajib memberikan mut'ah bila menjatuhkan țalaq (menceraikan istrinya) sebagai konpensasi dari terjadinya perceraian yang dijatuhkan, atau 'iwaäd sebagai ganti atau tebusan dari tuntutan cerai dari istri.

4. Ayat-Ayat yang membangun aturan radäah dan wanita yang haram dinikahi antara lain; QS. al-Nisā' (4): 22-24; QS. alBaqarah (2): 221, 235; Ayat-ayat tersebut di atas memberikan 
aturan tentang larangan melakukan pernikahan seorang pria dan wanita disebabkan oleh keadaan berikut; 7

a. Karena pertalian nasab;

1) Seorang perempuan yang melahirkan atau yang melahirkannya atau keturunannya

2) Seorang perempuan keturunan ayah atau ibu

3) Seorang saudara yang melahirkannya

b. Karena pertalian kerabat semenda

1) Seorang perempuan yang melahirkan istrinya atau mantan istrinya

2) Seorang perempuan mantan istri ayah yang menurunkannya

3) Seorang perempuan keturunan istri atau mantan istrinya, kecuali putusnya hubungan perkawinan dengan mantan istrinya itu sebelum hubungan (qabla al-dubūt)

4) Seorang perempuan mantan istri keturunannya

c. Karena pertalian sesusuan

1) Seorang perempuan yang menyusuinya dan seterusnya menurut garis lurus keatas

2) Seorang perempuan sesusuan dan seterusnya menurut garis lurus ke bawah

3) Seorang perempuan saudara sesusuan dan kemenakan sesuan ke bawah

4) Seorang perempuan bibi sesusuan dan nenek bibi sesusuan ke atas

5) Anak perempuan yang disusui oleh istrinya dan keturunannya

d. Karena dalam keadaan tertentu

1) Seorang perempuan yang masih terikat satu perkawinan dengan pria lain

2) Seorang perempuan yang masih berada dalam masa iddah

3) Seorang perempuan musyrik

5. Ayat-ayat yang membangun dasar atau pedoman yang mengatur kehidupan rumah tangga, yang mencakup: hak dan kewajiban suami, istri dan anak, bisa juga diartikan bahwasanya ini

7 Istilah yang digunakan oleh Kompilasi Hukum Islam pasal 39. 
mencakup urusan hubungan orang tua dan anak-anaknya. Sub ini juga mencakup poligami, dan nafkah.

Ayat-Ayat tentang Hak dan Kewajiban Suami, Istri, Anak, Perwalian dan Masalah Nafkah antara lain; Q.S. al-Baqarah (2): 233, Q.S. al-Țalāq (65): 6-7; Q.S. al-Nūr (24): 33, QS. al-Nisāà (4): 32, 34, QS. al-Ahzāb (33): 35. Ayat-ayat membangun hak dan kewajiban suami maupun istri dalam kehidupan rumah tangga dan pemeliharaan serta membentuk kualitas anak-anak mereka dalam menjaga tujuan perkawinan yang sakinah, mawaddah (penuh cinta), dan rahmah (kasih sayang). Hak dan kewajiban tersebut dapat dijelaskan dalam tabel berikut;8

Tabel 3.4

Hak dan Kewajiban Suami

\begin{tabular}{|l|l|l|}
\hline No & \multicolumn{1}{|c|}{ Hak } & \multicolumn{1}{c|}{ Kewajiban } \\
\hline 1 & Dipatuhi / diikuti & Memberikan mahar \\
\hline 2 & Amanah & Memberikan nafkah \\
\hline 3 & $\begin{array}{l}\text { Diperlakukan secara } \\
\text { ma'rüf }\end{array}$ & $\begin{array}{l}\text { Memperlakukan } \\
\text { secara ma'rüf }\end{array}$ \\
\hline 4 & Melindungi & $\begin{array}{l}\text { Memberikan tempat } \\
\text { tinggal }\end{array}$ \\
\hline 5 & Mendidik & $\begin{array}{l}\text { Memberikan } \\
\text { pendidikan }\end{array}$ \\
\hline 6 & Membimbing & Mengangkat martabat \\
\hline 7 & Meninggalkan ranjang & $\begin{array}{l}\text { Memenuhi kebutuhan } \\
\text { ekonomi }\end{array}$ \\
\hline 8 & $\begin{array}{l}\text { Memberi } \\
\text { pelajaran/sanksi }\end{array}$ & $\begin{array}{l}\text { Menjaga } \\
\text { keharmonisan } \\
\text { keluarga }\end{array}$ \\
\hline 9 & Mengajukan mediasi & $\begin{array}{l}\text { Menjamin keutuhan } \\
\text { keluarga }\end{array}$ \\
\hline 10 & $\begin{array}{l}\text { Menuntut kesucian } \\
\text { diri istri }\end{array}$ & Menyiapkan fasilitas \\
\hline 11 & $\begin{array}{l}\text { Didampingi dalam } \\
\text { bepergian }\end{array}$ & $\begin{array}{l}\text { Memberikan } \\
\text { perlindungan }\end{array}$ \\
\hline
\end{tabular}

8 al-Zuhayly, al-Fiqh al-Isläm, 7842. 
Suqiyah Musafa'ah: Tafsir Maqasid dengan Pendekatan Gender...

\begin{tabular}{|c|l|l|}
\hline 12 & $\begin{array}{l}\text { Melakukan perbuatan } \\
\text { hukum }\end{array}$ & $\begin{array}{l}\text { Menanggung resiko } \\
\text { dan konsekuensinya }\end{array}$ \\
\hline 13 & Mewarisi & Menjadi wali \\
\hline 14 & Menjatuhkan Talaq & Memberikan mut'ah \\
\hline
\end{tabular}

Tabel 3.5

Hak dan Kewajiban Istri

\begin{tabular}{|c|c|c|}
\hline $\mathrm{No}$ & Hak & Kewajiban \\
\hline & Finansial & \\
\hline 1 & Mahar & Melayani suami \\
\hline 2 & Nafkah & $\begin{array}{l}\text { Mengatur } \\
\text { /mengelola ekonomi } \\
\text { keluarga }\end{array}$ \\
\hline 3 & Tempat tinggal & $\begin{array}{l}\text { Menjaga kenyamanan } \\
\text { lingkungan }\end{array}$ \\
\hline 4 & Pakaian & Menjaga kehormatan \\
\hline 5 & Harta waris & \\
\hline 6 & Wasiyat & Mematuhi suami \\
\hline 7 & $\begin{array}{l}\text { Diperlakukan secara } \\
\text { ma'rūf }\end{array}$ & $\begin{array}{l}\text { Memperlakukan } \\
\text { secara ma'rüf }\end{array}$ \\
\hline & Non finansial & \\
\hline 8 & Perlakuan'adālah & \\
\hline 9 & $\begin{array}{l}\text { Keharmonisan dalam } \\
\text { hubungan suami dan } \\
\text { istri }\end{array}$ & $\begin{array}{l}\text { Menjamin keutuhan } \\
\text { keluarga }\end{array}$ \\
\hline 10 & $\begin{array}{l}\text { Bebas menjalankan } \\
\text { ibadah }\end{array}$ & \\
\hline 11 & $\begin{array}{l}\text { Memperoleh } \\
\text { Pendidikan }\end{array}$ & Mendidik anak \\
\hline 12 & $\begin{array}{l}\text { Melakukan perbuatan } \\
\text { hukum }\end{array}$ & $\begin{array}{l}\text { Menanggung resiko } \\
\text { dan konsekuensinya }\end{array}$ \\
\hline 13 & Berkarya & Menjaga amanah \\
\hline 14 & $\begin{array}{l}\text { Khulü'/menggugat } \\
\text { cerai }\end{array}$ & Menyerahkan iwad \\
\hline
\end{tabular}


Tabel 3.6

Hak Anak

\begin{tabular}{|l|l|}
\hline No & \multicolumn{1}{|c|}{ Hak } \\
\hline 1 & Hidup bermartabat \\
\hline 2 & Hidup sehat \\
\hline 3 & Mendapatkan perlindungan \\
\hline 4 & Mendapatkan pendidikan \\
\hline 5 & Mendapatkan nafkah \\
\hline 6 & Diperlakukan secara ma'rüf \\
\hline 7 & Memperolehkan tempat tinggal \\
\hline 8 & Pakean penutup aurat \\
\hline 9 & Mendapatkan bimbingan \\
\hline 10 & Terpenuhi kebutuhan ekonomi \\
\hline 11 & Terjaga kehormatannya \\
\hline 12 & Perwalian \\
\hline 13 & Mewarisi \\
\hline 14 & wasiyat \\
\hline
\end{tabular}

6. Ayat-Ayat hukum Poligami antara lain; QS. al-Nisāa (4): 3, QS. al-Ahzāb (33): 50-53, QS. al-Nisā' (4): 129. Ayat-ayat tersebut memberikan penjelasan bahwa poligami dalam perkawinan sesungguhnya merupakan hak khusus bagi Nabi saw. Hukum asal perkawinan menurut al-Qur'an adalah monogami, poligami hanya sebagai jalan keluar bagi masalah yang darury (emergency exit). 9

7. Ayat-Ayat Hukum Perceraian antara lain;

a. Ayat tentang Nushür, Shiqāq dan penyelesaiannya antara lain; QS. al-Nisā' (4): 34-35, 128. Ayat-ayat tersebut menjelaskan tentang Nushür, Shiqāq dan solusinya.

Nushü adalah meninggalkan kewajiban bersuami istri. Nushüz dari pihak istri seperti melakukan kegiatan tanpa izin suaminya, sehingga mengabaikan hak-hak suami. Nushüz dari

9 M.Rashīd Ridā, Tafsìr al-Qur'ān al-Hakm/al-Mannār, (Beirut: Dār al-Kutub alIlmiyah, 2005), jilid 4, 248. 
pihak suami ialah bersikap keras terhadap istrinya; tidak mau menggaulinya dan tidak mau memberikan hak istri.10

Bila terjadi nushür, yang menyebabkan retaknya hubungan dan keharmonisan perkawinannya atau terjadi shiqāq yang terancam putus ikatan perkawinannya, maka alQur'an memberikan saran, agar keduanya mengadakan mediasi, melalui mediator yang mewakili kedua pasangan untuk memberikan nasehat dan mendamaikan pasangan tersebut.

b. Ayat -ayat hukum Talak dan Rujuk antara lain berisi aturan tentang tata cara mentalaq istri dan etika memperlakukannya antara lain; QS. al-Baqarah (2): 228-230, 231-232, 236, 237, 240, 241, QS. al-Nisā' (4): 19, 34; QS. al-Țalāq (65): 1,2,3;

Ayat-ayat tersebut di atas memberikan aturan, etika dan tata cara menggugat cerai, baik oleh suami maupun istri, dan konsekuensinya. Aturan ţalāq yang bisa dirujuk itu hanya dua kali, bila melebihi, maka harus ada lelaki lain yang menikahinya.

Perceraian merupakan pintu sempit "emergency exit", ${ }_{11}$ banyak Hadith Nabi saw yang mengancam terjadinya perceraian. Karena itu al-Qur'an hanya memberikan kesempatan dua kali, bila terjadi lebih dari itu, maka perkawinannya harus diakhiri, dan istrinya harus dinikahi oleh lelaki lain dulu, baru boleh kembali sebagai sanksi atas ketidak mampuan pasangan dalam mempertahankan ikatan perkawinan mereka.12

Putusnya ikatan perkawinan harus melalui tahapan sebagai berikut;13 melakukan komunikasi secara baik, harus berusaha bertahan, dan berusaha menahan derita, baru kemudian suami dan istri harus saling memberi nasehat dan melakukan introspeksi diri masing-masing14, bila tidak berhasil, maka usaha selanjutnya adalah pisah ranjang, bila

10 Departemen Agama RI, Al-Qur'an dan Terjemahnya,

11 Al-Zuhayly, dalam al-Fiqh al-Islam, 6875.

12 Q.S. al-Baqarah (2): 230

13 Al-Zuhayly, dalam al-Fiqh al-Isläm, 6876.

14 QS.Ali Imran (3): 159. 
usaha kedua ini gagal, maka baru dibenarkan melakukan tindakan yang mengarah pada putusnya ikatan perkawinan melalui pihak ketiga dalam rangka memberikan klarifikasi dan usaha mendamaikan pasangan suami dan istri tersebut.

Rasulullah dalam sunnahnya menunjukkan sikap tidak setuju dengan sikap para Sahabatnya yang melakukan kekerasan kepada istrinya, sehingga beliau menyarankan untuk melakukan qişăs. 15

Bila ikatan perkawinan telah putus, baik atas keinginan suami maupun istri,16 maka pihak yang menginginkan dibebani tanggungjawab untuk menyerahkan konpensasi putusnya hubungan perkawinan tersebut. Di samping itu keduanya harus tetap menjaga hubungan dengan baik, tanpa melupakan kebaikan selama hidup bersama.17

Al-Qur'an tidak menentukan besaran mut'ah atau tebusan yang harus diserahkan kepada suami atau istri pasca perceraian, demikian juga anjuran untuk bersikap yang ma'ruf atau kesalehan sosial terhadap asangan selama masa iddah.

Dalam proses perceraian tersebut, istri tidak boleh menyembunyikan kehamilannya kepada suami, dan harus melaksanakan masa iddah. Kecuali bagi yang belum disentuh oleh suaminya. Bila terjadi perceraian dan selama mengikat perkawinan belum pernah melakukan hubungan suami-istri, dan mahar juga belum ditentukan, maka tidak wajib membayar mahar, tetapi bila sudah menentukan, maka boleh membayar separuh. Tapi bila Wali mema'afkan, maka suami dibebaskan dari membayar mahar yang seperdua, sedang kalau suami yang mema'afkan, Maka Dia membayar seluruh mahar.

Selama masa perkawinan, suami tidak diperkenankan berlaku semena-mena, yang membuat istri menderita dan terpasung hidupnya, dengan cara menceraikan, lalu ketika masa iddabnya hampir habis, mereka meminta kembali atau

15 Sebagaimana dijelaskan dalam riwayat sabab nuzul ayat 34 QS. al-Nisā' (4).

16 Q.S. al-Baqarah (2): 229.

17 Q.S. al-Baqarah (2): 237. 
ruju', dengan tujuan agar istrinya tidak bisa menikah dengan orang lain, dan tidak pernah bisa bebas.18

Pelaksanaan perceraian harus disaksikan oleh dua orang saksi yang adil, jujur dan terpecaya. Dan persaksian tersebut harus ditegakkan.

c. Ayat tentang hukum $I l \vec{a}$ dan $q i b \bar{a} r$ dan konsekuennya antara lain; QS. al-Baqarah (2): 226-227, QS. al-Nūr (24): 6-9, QS. alMujādalah (58): 1-4.

Meng-ilaa' istri maksudnya adalah bersumpah tidak akan mencampuri istri, dengan sumpah ini seorang wanita menderita, karena tidak disetubuhi dan tidak pula diceraikan. Dengan turunnya ayat ini, maka seorang suami diberi tangguh waktu untuk berfikir selama 4 bulan, untuk memilih antara kembali menyetubuhi istrinya lagi dengan membayar kafarat sumpah atau menceraikan. Tetapi Allah menginginkan kembali ruju' sebagaimana sepirit ayat 226 QS. al-Baqarah (2).

Orang yang menuduh Istrinya berbuat zina dengan tidak mengajukan empat orang saksi, maka harus melakukan sumpah dengan nama Allah empat kali, bahwa Dia adalah benar dalam tuduhannya itu. kemudian Dia bersumpah sekali lagi bahwa Dia akan kena laknat Allah jika Dia berdusta. Masalah ini dalam fiqih dikenal dengan sumpah Li'an. QS. alNūr (24): 6-9 diterapkan oleh Rasulullah saw ketika di Madinah dalam menyelesaikan kasus sahabat Anșār yang menuduh istrinya melakukan zina, setelah sepasang suami istri telah melakukan sumpah li'an, lalu Rasulullah saw menfasakh atau menceraikan keduanya 19

Sebab turun ayat QS. al-Mujādalah (58): 1-4 ini ialah berhubungan dengan persoalan seorang wanita bernama Khaulah binti Tha labah yang telah di zibäroleh suaminya Aus ibn Shamit, Yaitu dengan mengatakan kepada istrinya;" kamu bagiku seperti punggung ibuku" dengan maksud Dia tidak boleh lagi menggauli istrinya, sebagaimana ia tidak boleh menggauli ibunya.

18 Q.S. al-Baqarah (2): 231.

19 Qamaruddin Shaleh, A.A.Dahlan, M.D.Dahlan, Asbabun Nuqul, Latar Belakang Historis Turunny ayat-ayat alQur'an, (Bandung: C.V. Diponegoro, t.th), 337. 
Menurut adat Jahiliyah kalimat zihär seperti itu sudah sama dengan menthalak istri. Maka Khaulah mengadukan hal itu kepada Rasulullah s.a.w. Rasulullah menjawab, bahwa dalam hal ini belum ada keputusan dari Allah.

Ayat-ayat tersebut merupakan aturan dan pemberian sanksi kepada suami yang melakukan ziihär. Zihär pada masa Jahiliyah merupakan salah satu bentuk seorang suami menjatuhkan țalaq, lalu ayat-ayat tersebut memberikan solusi dengan membayar kafarät ziihär atau sanksi sumpah zi i̧är dengan membebaskan budak muslimah. Maka bila suami telah membayar kafarāt, mereka bisa kembali sebagai suami istri.

d. Ayat tentang Iddah dan hukumnya serta konsekuensinya antara lain; QS. al-Baqarah (2): 228, 231, 234-235, QS. alȚalāq (65): 4-7, QS. al-Ahzāb (33): 49;

Ayat-ayat tersebut di atas memberikan aturan tentang $i d d a h$ dan konsekuensinya, yang dapat dijelaskan dalam tabel berikut;

Tabel 3. 7

Jenis Iddah

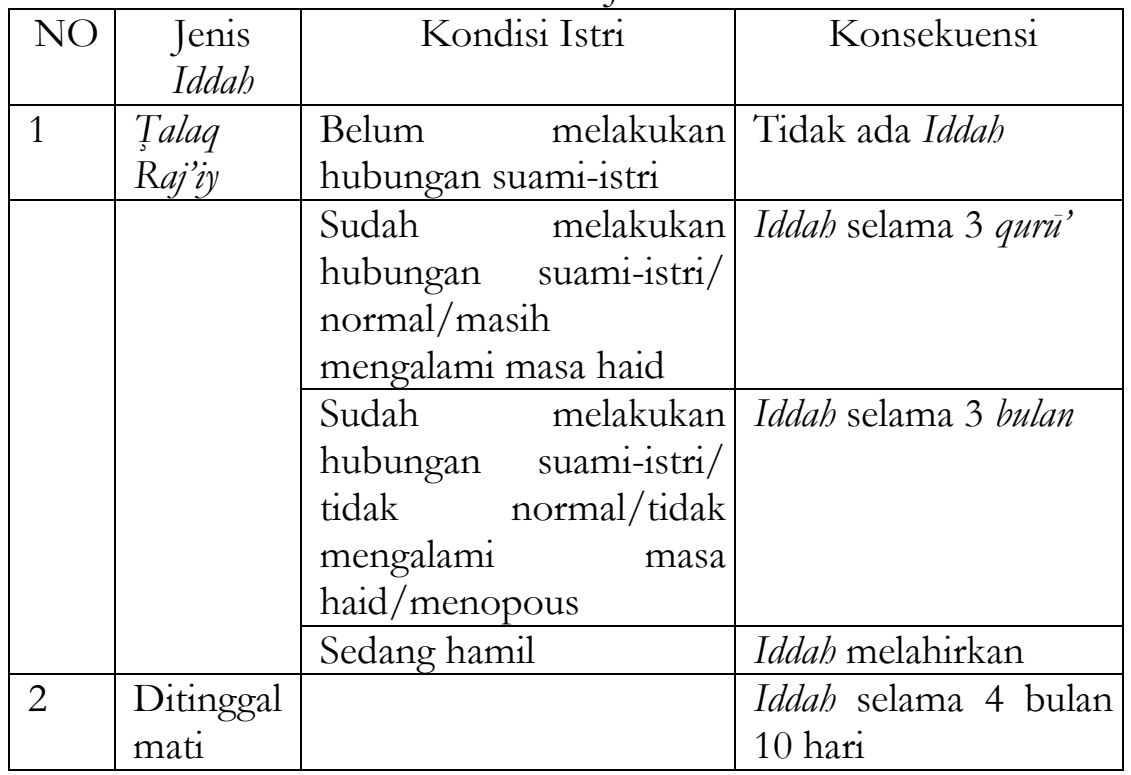


Suqiyah Musafa'ah: Tafsir Maqasid dengan Pendekatan Gender..

Selama masa iddah perempuan yang dicerai berhak mendapatkan nafkah, dan tempat tinggal, dan tetap menjaga hubungan baik dan tidak melupakan kebaikan masing-masing selama masa perkawinan mereka.

8. Ayat-Ayat Hukum Hadanah dan Adopsi antara lain; QS. alBaqarah (2): 220, QS. al-Nisā’ (4): 2, 5-6, 9-10, 127, QS. al-Ahzāb (33): 4-5; Ayat-ayat tersebut memberikan aturan cara menjaga, dan menjamin masa depan anak-anak akibat perceraian dan ditinggal mati orangtuanya. Harta mereka harus dikelola secara profesional demi masa depan mereka. Tidak boleh membuat mereka terlantar dan menyulitkan kehidupan mereka.

Ayat-ayat tersebut memberikan aturan cara mengadopsi anak. Bahwa status anak angkat tidak boleh menghilangkan asal usul keturunannya ke atas maupun menyamping, anak angkat tidak memiliki hak waris, tetapi berhak menerima wasiyat atau hibah.

9. Ayat-Ayat Wasiyat, Kewarisan dan Wakaf

a. Ayat-Ayat Hukum wasiyat

Pada masa Jahiliyah wasiyat tidak kepada orang tua dan keluarga atau istri, tetapi kepada orang lain dan kepala suku, demi menjaga popularitas dan prestise mereka, 20 karena itulah QS.al-Baqarah (2): 180, QS.al-Baqarah (2): 240 mengatur masalah wasiyat terutama kepada kedua orang, para kerabat, anak angkat, dan istri sebelum ayat waris turun.

b. Ayat-Ayat Kewarisan antara lain; QS. al-Nisā' (4): ) 7, 9, 1112,19, 33 dan 176. Ayat-ayat tersebut mengatur pembagian warisan akibat terjadinya ikatan perkawinan disamping faktor keturunan. Baik hak waris buat suami, istri, maupun anakanak mereka.

c. Ayat-Ayat Hukum Wakaf antara lain; QS. Ali-Imrān (3): 92, Surat Al-Hajj (22): 77, QS. Al-Baqarah (2): 261, QS. AlBaqarah (2): 267; Ayat-ayat tersebut mengatur perbuatan hukum seseorang yang memisahkan sebagian dari harta miliknya untuk kepentingan umum. Hukum wakaf masuk

20 Ibnu 'Ashūr, al-Tahrìr wa al-Tanwìr, (Tunis: Dār Sahnun li al-Nashr wa al-Tawzī', t.th.), II:127. 
dalam hukum keluarga adalah karena ia bagian dari dana keluarga yang dikeluarkan demi kepentingan umum.

\section{Penafsiran Ayat-Ayat Hukum Keluarga Pada Masa Sahabat}

Penafsiran pada masa Sahabat telah mengalami perkembangan yang dinamis sejalan dengan kebutuhan dan bentuk masyarakatnya, misalnya karakter penafsiran di wilayah Makkah sangat dipengaruhi oleh corak penafsiran Ibnu Abbās, karakter penafsiran di wilayah Madinah oleh Ubay bin Ka'ab, dan karakter penafsiran di wilayah Irak oleh Ibnu Mas'ud.21

Disamping tiga tokoh Sahabat Nabi tersebut, Umar bin Khațțāb r.a juga sangat kontroversial sejak mendampingi Rasulullah hingga masa pemerintahannya dalam menyelesaikan kasus hukum era awal Islam. Umar sangat tegas dalam mengaplikasikan aturan al-Qur'an yang tertuang dalam QS. AlBaqarah (2): 221. Turunnya aturan larangan kepada kaum muslim menikahi wanita musyrik dalam ayat tersebut, mendasari kebijakannya mengabaikan toleransi hukum yang tertuang dalam QS. Al-Māidah (5): 5, sikapnya tersebut dilatar belakangi oleh kekuawatiran Umar akan integritas masyarakat muslim dalam menegakkan nilai-nilai peradaban Islam yang disinari oleh alQur'an.22

Umar juga banyak memberikan inspirasi lahirnya ijtihad baru dalam hukum kewarisan, misalnya kasus kewarisan yang terjadi, ketika ahli waris adalah suami (1/2), ibu (1/3) dan saudara perempuan $(1 / 2)$. Kasus tersebut oleh Umar dikonsultasikan kepada beberapa Sahabat Nabi,23 dan disarankan untuk mengaplikasikan prinsip aul, yakni mengurangi bagian masingmasing sesuai proporsi bagiannya. 24

21 Al-Dhahabi,al-Tafsir wa al-Mufassirün (t.t.: t.p.,1976), juz 1, 118.

22 Abdullah Saeed, Al-Qur'an Abad 21, Tafsir Kontekstual, penerjemah, Ervan Nurtawab dari "Reading the Qur'an in the Twenty-first Century A Contextualist Approach", (Bandung: Mizan Pustaka, 2016), 62-63.

23 Diantaranya Ali bin Abu Țālib k.w.Al-Zuhayly, al-Fiqh al-Islāmy wa adillatuh, jilid. $\mathrm{X}, 7805$.

24 Alā' al-Dīn al Mardawi, al-Inshāf (t.t.: Dār al-Ihyäa' al-Turāth al Arabiy, 1986), dalam Abdullah Saeed, Al-Qur'an Abad 21, 64. 
Umar juga dikenal sebagai penggagas prinsip gharrawain yaitu masalah yang timbul akibat dari terjadinya bagian Ibu muwarrith lebih besar dari bagian Ayah muwarrith, sehingga lahir gagasan ini untuk menjaga spirit al-Qur'an, maka bagian Ibu muwarrith menjadi $1 / 3$ dari sisa pembagian harta waris. Masalah Gharrawain dimungkinkan terjadi ketika Ibu muwarrith dan Ayah muwarrith bersama Suami atau Istri.25

Umar juga menggagas prinsip mushärakah, yaitu masalah yang timbul akibat dari terjadinya saudara sekandung (bukan seayah) tidak mendapat harta waris, padahal diantara ahli waris ada saudara seibu muwarrith, mendapat bagian tertentu. Hal ini menimbulkan ketidakadilan, karena saudara sekandung memiliki hubungan yang lebih kuat dan lebih dekat dengan muwarrith. Kasus ini dimungkinkan terjadi bila ahli waris terdiri dari suami muwarrith, Ibu/nenek muwarrith, 2 saudara/i seibu atau lebih, dan 1 / lebih saudara sekandung.26

Selain gagasan prinsip aul, para Sahabat juga menggagas lahirnya prisip rädd, yaitu suatu masalah yang timbul akibat dari terjadinya bagian ahli waris yang berhak mendapat harta waris lebih kecil dari harta waris yang ditinggalkan muwarrith, sehingga ada sisa harta waris. Kasus ini terjadi bila ahli waris terdiri dari ibu dan puteri munarrith atau pewaris. Namun dalam aplikasinya mereka berbeda pendapat. Ada yang berpendapat kelebihannya tidak dibagikan kepada ahli waris yang sdh punya bagian tertentu, tetapi diserahkan ke kas negara. Pendapat ini adalah pendapat Zayd bin Thābit. Sedang Uthmān bin 'Affān berpendapat bahwa kelebihannya dibagikan kepada semua ahli warith. Sahabat Ali bin Abu T,ālib mengecualikan suami atau istri, sedang Ibnu Abbās mengecualikan suami atau istri dan nenek.27

Selain gagasan di atas Umar juga berijtihad dalam menetapkan kebijakan mengenai umm al-walad yang melahirkan anak dari majikannya dengan kebebasan dirinya dari status budak,

$25 \mathrm{Al}$-Zuhayly, al-Fiqh al-Islämy wa adillatuh, jilid. X, 7805.

26 Ibid. jilid. X, 7807-7808.

27 Ibid. jilid. X, 7825-7826. 
meski hal ini tidak diaplikasikan pada masa Rasulullah saw atau Abu Bakar r.a. karena masalah ini tidak dijelaskan oleh al-Qur'an.28

Disamping itu banyak ayat-ayat yang masih sangat global dan maknanya pun masih memuat banyak makna, misalnya QS. Al-

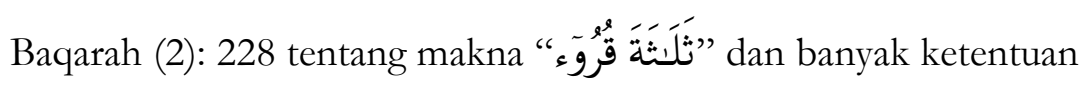
hukum yang masih bersifat umum, misalnya tentang ketentuan mahar, keharusan izin wali dalam perkawinan, ketentuan nafkah, jenis tempat tinggal, hak dan kewajiban suami istri dan lain sebagainya.

Pada era Sahabat, peran sabab nu₹ūl atau setting sejarah turunnya ayat menjadi perhatian dalam pertimbangan hukum yang dibangun. Demikian juga Sunnah Rasul sangat dijunjung selama memiliki sanad yang şahīh, bahkan menjadi sumber utama dalam menerjemahkan ketetapan ayat-ayat al-Qur'an.

\section{Penafsiran Ayat-Ayat Hukum Keluarga Pada Masa Tabi'in dan Madhhab}

Penafsiran pada masa tabi'in terhadap ayat-ayat hukum keluarga merupakan perkembangan tafsir pada masa Sahabat hingga selanjutnya melahirkan aliran dalam hukum Islam akibat perbedaan metode dan corak penafsirannya terhadap ayat-ayat hukum. Misalnya penafsiran terhadap QS. al-Nisā' (4): 24, yang membangun lahirnya perbedaan pendapat tentang hukum nikah mut'ah di kalangan Sunny dan Syi'ah, kecuali shi'ah Zaydiyah.29

QS. al-Nūr (24): 32 melahirkan perbedaan hukum tentang keharusan adanya wali nikah bagi seorang gadis.30 QS.al-Nisā'(4): 34 berpotensi melahirkan hukum keluarga yang melahirkan dominasi suami atas istrinya, karena pada perkembangannya, konteks nushüz selalu diarahkan oleh sikap istri yang melawan atau durhaka kepada suami, bukan sebaliknya, sehingga kemudian

28 Abdullah Saeed, Interpreting the Qur'ān. (London and New York: Roudledge, 2006), 67.

29 Al-Zuhayly, al-Fiqh al-Islāmy wa adillatuh (Suriyah.: Dār al-Fikr, 2004), juz: IX, 6553-6554.

30 Al-Razi, Tafsìr al-Rā̄ì., (t.t.: http://www.altafsir.com, t.th.), juz. XI, 311. 
pembenaran terhadap sanksi yang dilakukan oleh suami menjadi hal yang wajar.

QS. Al-Baqarah (2): 229 meski sudah nampak jelas, tetapi dalam aplikasinya menimbulkan masalah, apakah harus terucapkan maksud țalaqnya atau tidak, demikian juga implikasi dan konsekuensinya. Demikian juga dengan aplikasi konsep radäah dalam QS.al-Nisā'(4): 23. Ketentuan dan batasannya menimbulkan perbedaan pendapat.31 Demikian juga ayat-ayat waris yang disederhanakan hanya menjadi tiga ayat saja, yakni QS.al-Nisă’(4): 11-12, dan 176. Dan pernyataan “汭” dalam ayat 11 QS.al-Nisā'(4) telah dikukuhkan sebagai kaidah asal dalam menentukan bagian waris, sehingga produk hukum dari kaidah tersebut melahirkan kreatifitas ijtihad di kalangan Tabi'in sebagaimana yang dilakukan oleh para Sahabat, sehingga melahirkan madhhab dalam hukum Islam, di kalangan Malikiyah, Hanabilah, Hanafiyah dan Shafi'iyah tentang aplikasi penyelesaian kewarisan, bila terjadi kasus aul, radd, mushärakah dan sebagainya.

Era ini sangat didominasi oleh kelompok Shi'ah, kelompok Sunny yang dikenal dengan empat madhhab; Maliky, Hanbali, Hanafy, dan Shafi'iy, lalu kelompok Mu'tazilah. Salah satu contoh model penafsiran di kalangan Sunny dan Shi'ah terhadap QS. alNisā' (4): 24, menurut kelompok Shi'ah, bahwa hukum nikah mut'ah boleh, sedang menurut Sunny dan Shi'ah Zaydiyah, nikah mut'ah itu haram, karena banyak mengandung resiko, terutama bagi perempuan, pernikahan ini hanya sebagai emergency exit.32

Pada era ini model penafsiran akibat metode, dan dasar ijtihad yang digunakan oleh para pakar hukum benar-benar sangat mempengaruhi hasil ijtihad mereka. Namun isu hukum keluarga masih dalam frame masyarakat partiarki, misalnya kewajiban melakukan $i d d a h$ hanya diwajibkan kepada para istri, sedang suami wajib menanggung nafkahnya. Demikian juga pemeliharaan anak dan pemenuhan ekonomi dan pendidikannya juga menjadi

31 Muhammad Abu Zahrah, al-Ahwāl al-Shakhşiyah (t.t.: Dār al-Fikr al-Arabiy. T.th.), 91-92.

32 Al-Zuhayly, al-Fiqh al-Islāmy wa adillatuh (Suriyah.: Dār al-Fikr, 2004), juz: IX, 6553, 6555. 
tanggungjawab suami. Keadaan ini kemudian menciptakan suasana ketergantungan perempuan kepada kaum lelaki sangat dominan, sehingga perempuan menjadi terjebak dalam pelayanan domistik.

\section{Penafsiran Ayat-Ayat Hukum Keluarga Pada Masa Modern}

Pada era modern ini Muhammad Abduh telah mempelopori penafsirannya dengan menggunakan metode sosio kultural yang belum lazim dikenal oleh kalangan mufassir. Dalam karya ini dia telah memahami QS. al-Nisā' (4): 3;33 berbeda dengan mufassir sebelumnya. Ia berpendapat, bahwa ayat ini membangun asas monogami dalam perkawinan. Karya ini kemudian memberikan inspirasi lahirnya karya-karya tafsir modern dalam rangka menghidupkan potensi Qur'an demi menjawab tantangan modernitas.

Abduh juga menjelaskan, bahwa masalah waris adalah bagian dari perlindungan terhadap penghidupan ekonomi anak-anak yatim, dan pihak-pihak yang termarjinalkan, termasuk para perempuan yang tidak bersuami dan para orang tua. Mereka pada era jahiliyah terabaikan, bahkan tertindas hak-hak hidup dan kehidupannya. Karena itu ayat-ayat waris diatur untuk melindungi hak-hak mereka, agar perputaran ekonomi tidak hanya didominasi oleh pihak-pihak yang kuat.34 Pesan yang ingin dibangun oleh Qur'an bukan hanya ketentuan pembagian waris saja, tetapi yang terpenting adalah upaya membangun sistem sosial yang bermartabat dan berkesetaraan gender bagi masyarakat melalui pemberian hak waris kepada anakanak yatim, baik laki maupun perempuan, para janda, dan orang tua, karena anak-anak perempuan pada masa itu tidak memiliki hak hidup. 35

Hazairin (1906), seorang tokoh pembaharu bidang hukum adat dan hukum Islam, telah melakukan penafsiran ayat-ayat hukum keluarga dengan menggunakan model penafsiran tematik, yang belum dikenal di kalangan pakar tafsir Indonesia. Dan pada saat yang bersamaan, seorang pakar tafsir beraliran shi'ah, Sayyid Muhammad Husain Thabathaba'i (1903) juga menggagas karya

33 M.Rashīd Ridā, Tafsìr al-Qur'ān al-Hakm/al-Mannār, jilid 4, 248.

34 Muhammad Abduh, dan Muhammad Rasyid Ridla. Tafsir al-Manār, Juz IV.

(Bairut: Dār al-Fikr), IV: 322-323.

35 Baca Q.s. al-Nahl (12):58. 
tafsirnya yang berjudul Tafsìr al-Mǐān dengan menggunakan penafsiran tematik.

Mereka menggunakan penafsiran ayat Qur'an dengan ayat Qur'an sebagaimana penafsiran yang dilakukan oleh Nabi s.a.w. hanya saja Hazairin menggunakan teori sosial antropologis dalam memahami ayat hukum keluarga yang melahirkan sistem masyarakat parental dan berpengaruh bagi sistem kewarisan yang sejalan dengan pemahaman masyarakat Indonesia (Jawa) sebagaimana QS. al-Nisa' (4) ayat 7 dan 33 dalam melengkapi ayat-ayat hukum waris. 36

Menurut Hazairin, bahwa kajian terhadap QS. al-Nisa' (4): 2324 ditinjau dari sisi sosio-antropologis akan melahirkan sistem masyarakat parental yang sangat penting dalam pembagian hak dan kewajiban dalam hukum keluarga, termasuk dalam pembagian hak waris. 37

Pemahaman Hazairin tersebut sangat mempengaruhi pembaharuan hukum di Indonesia, karena dia mampu mengadaptasikan hukum Islam yang terlahir dari pemahamannya terhadap ayat-ayat hukum al-Qur'an dengan hukum yang diterapkan oleh masyarakat Indonesia yang disebut dengan hukum adat, misalnya tentang hukum kewarisan pengganti, yang kemudian ditetapkan dalam KHI. Pola pemahaman ini juga terjadi dalam konsep harta gono-gini dalam KHI sebagai hasil produk ijtihad istişlähi tokoh Muslim Indonesia.

\section{Penafsiran Ayat-Ayat Hukum Keluarga Pada Masa Kini}

Penafsiran ayat-ayat Qur'an yang membangun hukum keluarga pada masa kini cenderung menggunakan pendekatan maqāssid dengan desain tematik. Kecenderungan tersebut dalam rangka menghadirkan ayat-ayat Qur'an sebagai way of life dan solusi bagi berbagai problem yang dihadapi oleh masyarakat post modern (kontemporer).

Upaya penafsiran hukum keluarga termasuk kewarisan di masa kini dapat ditemukan dalam pembacaan ayat-ayat hukum oleh

36 Hazairin. Hukum Kewarisan Bilateral menurut Qur'an dan Hadith. (Jakarta: Penerbit Tintamas, 1982).

37 Hazairin, Hendak Kemana Hukum Islam, (Jakarta: Tintamas, 1976), 14. 
Shahrur (lahir 11 April 1938)38, Naşr Hamid Abū Zaiyd (10 juli 1943),39dan Abdullah Saeed (28 Januari 1960)40.

Aplikasi teori hermeneutika Shahrur dikenal dengan istilah inter-tekstualitas dengan teknik sintagmatis-paradigmatis untuk menangkap pesan yang terkandung dalam teks Qur'an41 melalui teori budüd.42 Pandangan Shahrur tentang hukum keluarga dapat kita telusuri dari penjelasannya mengenai enam batasan dalam penetapan hukum yang dihasilkan dari pembacaan kontemporernya terhadap ayat-ayat hukum (umm al-Kitäb) yang menurutnya menjadi panduan bagi para mujtahid melalui interaksinya secara kreatif dalam bidang hukum. Dari keenam batasan tersebut di atas, posisi ayat hukum keluarga menempati lima batasan, yaitu 1,3,4,5, dan 6 .

QS. al-Nisā̄ (4): 34 menurut pembacaan Shahrur mengindikasikan adanya hubungan yang bersifat objektif antara laki dan perempuan. Ayat ini menurutnya harus berlaku universal di seluruh dunia. Ayat ini menyebutkan faktor-faktor yang menjadikan seorang lelaki memiliki peran pelindung bagi perempuan, bila faktor tersebut hilang, maka hilang pula peran pelindung tersebut. Atau jika

38 Muhammad Shahrur, Prinsip Dan Dasar Hermeneutika Hukum Islam Kontemporer tjm. Sahiron Syamsuddin. Yogyakarta: Penerbit eLSAQ Press' 2007). Terjemahan dari al-Kitab wa al-Qur'an: Qira'ah Mu'assirah 2, dan Metodologi Fiqh IslamKontemporer tjm. Sahiron Syamsuddin dan Burhanuddin Dzikri. Yogyakarta: Penerbit eLSAQ Press. Terjemahan dari Dirāsāt Islämiyah Mu'ausirah: Nahwa Ușūl al-Jadìdah li al-Fiqh al-Islāmì.

39 Nasr Hamid Abu Zayd, Dawäir al-Khauf: Qirāah fì Khițāb al-Mar'ah. (Beirut: alMarkaz al-Thaqafiy al-arabiy, 2000) atau Dekontruksi Geneder Krtik Wacana Perempuan dalam Islam, Tjm.Moch.Nur Ichwan. (Yogyakarta: SAMHA Press. 2003).

40 Abdullah Saeed, Interpreting the Qur'an: Interpreting The Qur'an: Toward a Contemporary Approach. (London and New York: Roudledge, 2006).

41 Sintagmatis-paradigmatis yakni dengan cara menggabungkan ayat-ayat al-Qur'ân yang memiliki titik persinggungan dan persamaan tema dalam surat-surat yang berbeda. Teknik sintagmatis bertujuan untuk menentukan makna yang paling tepat di antara makna-makna yang ada, setiap kata pasti dipengaruhi oleh hubungannya secara linear dengan kata-kata di sekelilingnya. Adapun tujuan analisis paradigmatis adalah pencarian dan pemahaman terhadap sebuah konsepkonsep dari simbol-simbol lain baik yang mendekati maupun yang berlawanan. Muhammad Shahrūr, Islam dan Iman : Aturan-aturan Pokok, terj. Sabrur R. Soenardi (Yogyakarta: Jendela, 2002), xx.

42 Muhammad Shahrur, Prinsip Dan Dasar Hermeneutika Hukum., 38-42. 
peran tersebut pindah kepada perempuan, maka beralih pula peran tersebut kepada perempuan. 43

Menurut pembacaan Shahrur terhadap ayat 34 QS. al-Nisā̄' (4) tersebut, bahwa unsur-unsur pembentuk faktor yang menjadikan laki-laki atau perempuan berperan sebagai pelindung adalah; kekuatan fisik (bimā fadalallāh ba'dahum 'alā ba'd), dan kekuatan finansial (wa bimà anfaqū min amwälibìm).44

Nushüz menurut Shahrur memuat makna kesewenangan, dan kesombongan dari sisi sosial, dan berarti penyimpangan atau pemisahan dari sisi seksual, maka bila terjadi hal itu disebabkan oleh salah satu dari pasangan suami-istri, maka cara penyelesaiannya adalah yang pertama dengan pemberian nasehat, bila belum berhasil, ditempuh jalan kedua, yaitu pisah ranjang, kedua cara ini dilakukan dengan cara tertutup, atau rahasia antara pasangan suami dan istri saja. Bila kedua cara ini belum juga berhasi, maka baru dilakukan dengan cara ketiga, yaitu "wadribübunna" menjaga jarak secara terangterangan, bukan dalam arti harfiyahnya seperti yang dihami selama ini, memukul atau menyakiti secara fisik. 45

Iddah menurut Shahrur adalah melepaskan tanggung jawab dan kasih sayang berdasarkan QS.al-Țalāq (65) :1, dan batasannya adalah larangan untuk menikah atau merencanakan. Adapun keharusan untuk berdiam diri atau membatasi pergaulan dengan laki-laki adalah bagian dari konstruk sosial, yang bisa berubah dan bisa berbeda dari waktu ke waktu. 46

Nasr Hamid Abū Zaiyd mengusulkan pembacaan ayat-ayat keluarga dan waris menggunakan metode penafsiran (hermeneutika) artikulasi dari proses kesinambungan (continuity) dan perubahan (change) yang berangkat dari teori makna (dalälah) dan signifikansi (magza) .47

Menurut Nasr Hamid, Qur'an sangat memperhatikan persoalan warisan, bahkan apabila ada kerabat, anak yatim, orang-

43 Muhammad Shahrur, Prinsip dan Dasar Hermeneutika Hukum Islam, 289.

44 Ibid., 270.

45 Ibid., 271-273.

46 Ibid., 281.

47 Nasr Hamid Abu Zayd, Dawāir al-Khaūf. Beirut: al-Markaz al-Thaqāfi al'Arabiy, t.t., 184. 
orang miskin tidak mendapatkan warisan, mereka harus diberi sedekah. Prinsip keadilan Qur'an melalui pemerataan distribusi harta benda di dalam masyarakat secara luas menunjukkan makna tersembunyi dengan tujuan supaya perputaran kekayaan tidak hanya dimonopoli oleh orang kaya.48

Dari data historis pra Islam, perempuan tidak mendapatkan warisan sedikitpun, bahkan jika ia ditinggal mati oleh suaminya, seorang perempuan dapat diwariskan. Warisan hanya milik laki-laki yang bisa berperang. Tradisi ini menunjukkan bahwa posisi perempuan pada pra Islam sangatlah tertindas. Inilah yang dimaksud dengan al-siyāq al-thaqäfi al-ijtimā'i. Dengan datangnya Islam, posisi perempuan mulai diangkat dan hak-hak mereka sebagai manusia sedikit demi sedikit mulai dipenuhi, termasuk hak untuk memperoleh warisan. 49

Setelah melakukan analisis konteks eksternal, Nasr Hamid beralih ke analisis Konteks bahasa (al-siyāq al-lugawr). Dalam konteks warisan ini, Nasr Hamid mengikuti analisis Muhammad Abduh, dimana ia menganalisis kalimat wa li al-nisäi nasibun min mä taraka alwälidāni wa al-aqrabün. Kalimat ini menunjukkan makna fardu (ketetapan). Hasil ini berangkat dari analisis struktur teks (munāsabab) yaitu hubungan 'ataf kalimat tersebut dengan kalimat sebelumnya, dan pengulangan kata nasib. .50

Adapun analisis terhadap redaksi li al-dhakari mithlu hazz alunthayaini dan yüsikeum fi aulädikum, merupakan bentuk penghapusan tradisi jahiliyah yang melarang perempuan mendapatkan warisan. Analisis ini tidak berhenti pada aspek gramatikal, karena akan melahirkan makna bagian laki-laki adalah dua kali lipat bagian perempuan. Oleh karenanya perlu dihubungkan dengan persoalam kesaksian perempuan, baik di lembaga peradilan maupun urusan perniagaan, sebagai al-siyāq däkbilī..51

Secara tekstual redaksi ayat menyebutkan satu banding dua, satu saksi laki-laki sama dengan dua saksi perempuan. Untuk menghindari makna tekstual tersebut, maka perlu dicari magzā

\footnotetext{
48 Ibid., 235.

49 Ibid.

50 Ibid., 232.

51 Ibid. 233.
} 
dengan cara menghubungkan teks dengan konteks sosio historis yang disebutkan sebelumnya, yang menghendaki penghapusan monopoli dan agar terjadi pemerataan. Magzā adalah keseimbangan, baik dalam agama, sosial, maupun kemasyarakatan. Sehingga prinsip kesetaraan berlaku pada konteks waris.52

Naşr Hamid juga mengutip pendapat Muhammad Shahrur dalam mendapatkan magza $\bar{a}$ teks waris, bahwa ungkapan yang menyatakan bagian laki-laki adalah dua kali bagian perempuan, dalam teks ini terdapat kesetaraan dengan teori budüd Shahrur, ia menjelaskan bahwa ungkapan tersebut merupakan batasan-batasan dan ketetapan Allah, yaitu supaya laki-laki tidak diberi warisan lebih dari dua kali lipat bagian perempuan, dan perempuan agar tidak diberikan lebih sedikit dari separoh bagian laki-laki. Dengan kata lain makna kesataraan dalam warisan adalah batas maksimal untuk lakilaki, dan batas minimal untuk perempuan.53

Upaya menjaga fleksibelitas makna ayat-ayat Qur'an sepanjang zaman, Abdullah Saeed membangun hirarki nilai dalam memahami ayat-ayat hukum keluarga termasuk hukum waris. Teori hirarki nilai tersebut menyempurnakan gagasan doble movement Fazlur Rahman. Hirarki nilai tersebut adalah; nilai-nilai yang bersifat kewajiban, nilai-nilai fundamental, nilai-nilai proteksional, nilai-nilai implementasional, dan nilai-nilai intruksional.54 Nilai-nilai yang bersifat kewajiban memiliki nilai tetap, tidak akan berubah (immutable), dan berpotensi menjadi doktrin agama yang abadi. Ayatayat ethico-legal yang masuk kategori ini antara lain; ayat-ayat yang membangun sistem kepercayaan (rukun iman), praktik ibadah, dan ayat-ayat yang berkaitan dengan masalah halal-haram. .55

Tujuan apapun yang termasuk maqāsid pasti untuk menyatakan kemaslahatan manusia atau mendatangkan manfaat dan menolak kemudaratan dari mereka. Kaidah yang dinyatakan oleh alQarrafi $(1285 \mathrm{H})$ tersebut ditempatkan sebagai landasan teori dalam memberikan penilaian penafsiran ayat-ayat hukum keluarga sejak masa Rasulullah saw sampai dengan sekarang.

52 Ibid. 231.

53 Ibid. 233-234.

54 Abdullah Saeed, Interpreting the Qur'ân., 129-130.

55 Ibid.130-131. 
Kajian terhadap cakupan ayat-ayat yang membangun hukum keluarga sebagaimana terangkum dalam tiga bidang hukum; yakni hukum Hukum Keluarga (usrah) yang dimulai dari peminangan sampai perpisahan, baik karena ada yang wafat maupun karena terjadi perceraian. Hukum kekayaan keluarga (amwāo); yang mencakup waris, wasiyat, wakaf dan sejenisnya yang berkaitan dengan penerimaan dan atau pemberian; dan hukum perwalian terhadap anak yang belum dewasa. Semua aturan hukum tersebut sesungguhnya dalam rangka membangun keluarga ideal sebagaimana digambarankan dalam QS. al-Rūm (30): 21. Karena itu analisis maqāşid terhadap penafsiran aturan atau hukum keluarga yang tertuang dalam ayat-ayat hukum tersebut dilakukan berdasarkan parameter tujuan perkawinan, yaitu mencapai kualitas hidup yang sakinah, mawaddah, dan rahmah. Sedang perspektif keadilan gender diidentifikasi berdasarkan keharmonisan melalui hubungan antara suami, isteri, dan anak yang mampu memenuhi hak dan kewajiban masing-masing dengan penuh cinta dan kasih sayang. Masing-masing memiliki kemampuan mengontrol hak dan kewajiban tersebut secara bebas dan proporsional.

\section{Penutup}

Ayat-ayat yang membangun Hukum Keluarga berdasarkan cakupannya antara lain; Ayat-ayat hukum keluarga (usrah) yang dimulai dari peminangan sampai perpisahan, baik karena ada yang wafat maupun karena terjadi perceraian, ayat-ayat hukum perwalian terhadap anak yang belum dewasa dan ayat-ayat hukum kekayaan keluarga (amwäl al-usrah) yang mencakup waris, wasiyat, wakaf dan sejenisnya yang berkaitan dengan penerimaan dan atau pemberian.

Penafsiran terhadap ayat-ayat tersebut dari perspektif maqūșid dengan pendekatan gender berpijak dari QS.al-Rūm (30): 21; bahwa aturan perkawinan bertujuan membangun keluarga yang sakinah (harmonis), yang melahirkan hubungan saling cinta diantara suami, istri, dan kasih sayang diantara anak-anak mereka. Keharmonisan tersebut terbangun melalui hubungan antara suami, isteri, dan anak yang mampu memenuhi hak dan kewajiban masing-masing dengan penuh cinta dan kasih sayang. Masing-masing memiliki kemampuan mengontrol hak dan kewajiban tersebut secara bebas dan proporsional. 
Berdasarkan kesimpulan tersebut di atas, maka penelitian ini menawarkan metode penafsiran al-Qur'an berdasarkan maqāşid dengan argumen keadilan gender, untuk menghasilkan pemahaman terhadap yat-ayat hukum keluarga yang berkeadian, dan sesuai konteks Islam Indonesia. Tawaran metodologis tersebut dalam rangka memperkuat karakter ijtihad istişlähiy dalam memahami ayatayat hukum keluarga, sehingga mampu memberikan solusi bagi berbagai problem hukum keluarga yang ada di tengah masyarakat Indonesia, dan kemudian merumuskankannya sebagai hukum positif yang bisa diterapkan untuk semua masyarakat Indonesia yang memeluk beragam agama.

\section{Daftar Pustaka}

Abdullah Saeed. Al-Qur'an Abad 21, Tafsir Kontekstual, penerjemah, Ervan Nurtawab dari "Reading the Qur'an in the Twentyfirst Century A Contextualist Approach", Bandung: Mizan Pustaka, 2016.

-----.. Interpreting the Qur'ân: Interpreting The Qur'an: Toward a Contemporary Approach, London and New York: Roudledge, 2006.

Alā' al-Dīn al Mardawi. al-Inshäf, t.t.: Dār al-Ihyāà al-Turāth al Arabiy, 1986, dalam Abdullah Saeed, Al-Qur'an Abad 21.

Ali bin Abu Țālib k.w.Al-Zuhayly. al-Fiqh al-Islämy wa adillatuh, jilid. $\mathrm{X}$.

Al-Dhahabi. al-Tafsir wa al-Mufassirün, t.t.: t.p.,1976, juz 1.

Hazairin. Hendak Kemana Hukum Islam, Jakarta: Tintamas, 1976.

. Hukum Kewarisan Bilateral menurut Qur'an dan Hadith, Jakarta:

Penerbit Tintamas, 1982.

Ibnu 'Ashūr. al-Tahrìr wa al-Tanwìr, Tunis: Dār Sahnun li al-Nashr wa al-Tawzì', t.th., II.

M.Rashīd Ridā. Tafsìr al-Qur'ān al-Hakm/al-Mannār, Beirut: Dār alKutub al-Ilmiyah, 2005, jilid 4.

Mansour Fakih. Analisis Gender dan Transformasi Sosial, Yogyakarta: Pustaka Pelajar, 1999.

Muhammad Abduh. dan Muhammad Rasyid Ridla. Tafsir al-Manār, Juz IV. (Bairut: Dār al-Fikr), IV.

Muhammad Abu Zahrah. al-Ahwäl al-Shakbssiyah, t.t.: Dār al-Fikr alArabiy. T.th.. 
Muhammad Shahrūr, Islam dan Iman : Aturan-aturan Pokok, terj. Sabrur R. Soenardi Yogyakarta: Jendela, 2002.

Muhammad Shahrur. Prinsip Dan Dasar Hermeneutika Hukum Islam Kontemporer tjm. Sahiron Syamsuddin. tjm. Sahiron Syamsuddin dan Burhanuddin Dzikri. Yogyakarta: Penerbit eLSAQ Press.

Nasr Hamid Abu Zayd. Dawäir al-Khaūf. Beirut: al-Markaz alThaqāfi al-'Arabiy, t.t..

Nasr Hamid Abu Zayd. Dawäir al-Khauf: Qiräah fì Khițäb al-Mar'ah.

(Beirut: al-Markaz al-Thaqafiy al-arabiy, 2000) atau Dekontruksi Geneder Krtik Wacana Perempuan dalam Islam, Tjm.Moch.Nur Ichwan, Yogyakarta: SAMHA Press. 2003.

Qamaruddin Shaleh. A.A.Dahlan, M.D.Dahlan, Asbabun Nuzul,

Latar Belakang Historis Turunya ayat-ayat alQur'an, Bandung:

C.V. Diponegoro, t.th.

Al-Razi. Tafsìr al-Rǟì, (t.t.: http://www.altafsir.com, t.th.), juz. XI.

Wahbah al-Zuhayly. al-Figh al-Isläm wa Adillatuh, Beirut: Dār al-Fikr, 2004.

Departemen Agama RI. Al-Qur'an dan Terjemabnya, 